\title{
Skin gradient of body temperature related to non- shivering thermogenesis 3 in humans at a lowered ambient temperature
}

Citation for published version (APA):

Westerterp-Plantenga, M. S., van Marken Lichtenbelt, W. D., \& Schrauwen, P. (2001). Skin gradient of body temperature related to non-shivering thermogenesis 3 in humans at a lowered ambient temperature. Journal of Thermal Biology, 26, 467-472. https://doi.org/10.1016/S0306-4565(01)00062-6

Document status and date:

Published: 01/01/2001

DOI:

10.1016/S0306-4565(01)00062-6

Document Version:

Publisher's PDF, also known as Version of record

\section{Document license:}

Taverne

Please check the document version of this publication:

- A submitted manuscript is the version of the article upon submission and before peer-review. There can be important differences between the submitted version and the official published version of record.

People interested in the research are advised to contact the author for the final version of the publication, or visit the DOI to the publisher's website.

- The final author version and the galley proof are versions of the publication after peer review.

- The final published version features the final layout of the paper including the volume, issue and page numbers.

Link to publication

\footnotetext{
General rights rights.

- You may freely distribute the URL identifying the publication in the public portal. please follow below link for the End User Agreement:

www.umlib.nl/taverne-license

Take down policy

If you believe that this document breaches copyright please contact us at:

repository@maastrichtuniversity.nl

providing details and we will investigate your claim.
}

Copyright and moral rights for the publications made accessible in the public portal are retained by the authors and/or other copyright owners and it is a condition of accessing publications that users recognise and abide by the legal requirements associated with these

- Users may download and print one copy of any publication from the public portal for the purpose of private study or research.

- You may not further distribute the material or use it for any profit-making activity or commercial gain

If the publication is distributed under the terms of Article $25 \mathrm{fa}$ of the Dutch Copyright Act, indicated by the "Taverne" license above, 


\title{
Core-skin gradient of body temperature related to non-shivering thermogenesis 3 in humans at a lowered ambient temperature
}

\author{
M.S. Westerterp-Plantenga*, W.D. van Marken Lichtenbelt, P. Schrauwen
}

Department of Human Biology, University of Maastricht, P.O. Box 616, 6200 Maastricht, The Netherlands

\begin{abstract}
We addressed the effect of lowered ambient temperatures i.e. $22^{\circ} \mathrm{C}\left(72^{\circ} \mathrm{F}\right)$ versus $27^{\circ} \mathrm{C}\left(81^{\circ} \mathrm{F}\right)$ in 8 women and $16^{\circ} \mathrm{C}$ $\left(61^{\circ} \mathrm{F}\right)$ versus $22^{\circ} \mathrm{C}\left(72^{\circ} \mathrm{F}\right)$ in 9 men as part of a $24 \mathrm{~h}$ non-shivering thermogenesis (NST3) measured in a respiration chamber. We defined this new concept, NST3 as total energy expenditure - (sleeping metabolic rate + diet-induced energy expenditure + activity related energy expenditure). This was $248 \pm 208 \mathrm{~kJ} / \mathrm{d}$ at $22^{\circ} \mathrm{C}$ and $714 \pm 505 \mathrm{~kJ} / \mathrm{d}$ at $16^{\circ} \mathrm{C}$, and was related to the core-skin body temperature gradient $(r=-0.95 ; p<0.001$ and $r=-0.7 ; p<0.05)$ thus limiting the increase in this gradient at a lower ambient temperature. (C) 2001 Elsevier Science Ltd. All rights reserved.
\end{abstract}

Keywords: Humans; Body temperature; Core-skin temperature gradient; Non-shivering thermogenesis; Energy metabolism; Respiration chamber

\section{Introduction}

In general, a significant relationship between body temperature and metabolic rate (Kraeuchi and WirzJustice, 1994; Refinetti, 1997), as well as between ambient temperature and metabolic rate has been shown. Older (e.g. Hardy and DuBois 1934, 1940), as well as more recent studies (Dauncey, 1981, Blaza and Garrow, 1983) showed an inverse relationship between heat production of the body, or metabolic rate, and ambient temperatures between 10 and $30^{\circ} \mathrm{C}$.

In two studies, we showed that with lowered ambient temperatures, i.e. $22^{\circ} \mathrm{C}\left(72^{\circ} \mathrm{F}\right)$ compared to $27^{\circ} \mathrm{C}\left(81^{\circ} \mathrm{F}\right)$ in 8 women (study I) and $16^{\circ} \mathrm{C}\left(61^{\circ} \mathrm{F}\right)$ compared to $22^{\circ} \mathrm{C}$ $\left(72^{\circ} \mathrm{F}\right)$ in 9 men (study II), total energy expenditure (EE) had increased. (Markenlichtenbelt et al., 2000; Westerterp-Plantenga et al., 2001a, b, submitted for publication). In study I, the energy spent on physical activity

*Corresponding author. Tel.: +31-43-3881617; fax: +31-433670976.

E-mail address: m.westerterp@hb.unimaas.nl (M.S. Westerterp-Plantenga).
(AEE) and on diet-induced energy expenditure (DEE) had increased; in study II, the sleeping metabolic rate (SMR) and the DEE had increased. Surprisingly, in both studies, the DEE had not only increased absolutely, but also relatively. In both studies the energy expenditure that has been measured as DEE is in fact resting energy expenditure (REE) consisting of DEE and a component of non-shivering thermogenesis (NST) which is defined below. DEE is the acute effect of food ingestion on REE, which in the average individual accounts for about 10-15 percent of EE (Rothwell et al., 1990; Westerterp-Plantenga et al., 1990, 1992, 1999; Reed and Hill, 1996; Westerterp et al., 1998). The primary determinants of DEE are the level of energy intake and the macronutrient composition of the food: with increasing energy intake and with relative increases of protein and/or carbohydrate contents, DEE increases (Rothwell et al., 1990; Reed and Hill, 1996; WesterterpPlantenga et al., 1999). DEE consists of an obligatory and a facultative component. The obligatory component represents the energy required for the processing of food; the facultative component represents increased sympathetic nervous system activity. Rothwell et al. 
(1990) already mentioned that the latter might contribute as NST to the temperature regulation of the body.

We define NST as the sum of NST1 (a part of SMR), NST2 (a part of DEE), and NST3 a part of REE). In both studies, EE measured as DEE is in fact REE, consisting of DEE and NST3. The way we usually determine DEE (i.e. as EE-(SMR + AEE)) allows us to determine NST3 as follows. When we have two comparable situations with respect to energy balance and macronutrient composition of energy intake, but the total energy expenditure is different, the absolute DEE should adapt, but the relative DEE, expressed as percentage energy from total energy intake should not change. If the relative DEE thus calculated appears to have changed, this change in fact represents NST3.

To test the hypothesis that NST3 would contribute to temperature regulation, we analyzed the effect of lowered ambient temperatures on body temperature measurements in relation to NST3, in a well-controlled but relatively normal situation, in energy balance conditions. The two situations with lowered temperatures were $22^{\circ} \mathrm{C}\left(72^{\circ} \mathrm{F}\right)$ versus $27^{\circ} \mathrm{C}\left(81^{\circ} \mathrm{F}\right)$, in 8 women and $16^{\circ} \mathrm{C}\left(61^{\circ} \mathrm{F}\right)$ versus $22^{\circ} \mathrm{C}\left(72^{\circ} \mathrm{F}\right)$, in 9 men. At a lower ambient temperature, we related the body temperature measurements to NST3, thus testing the hypothesis that this might contribute to body temperature regulation.

\section{Materials and methods}

\subsection{Subjects}

Eight healthy female and 9 healthy male volunteers participated in these studies. They were recruited from among University students. Physical characteristics for the females were (mean $\pm \mathrm{SD}$ ): age (yr) $23 \pm 2$, BMI $\left(\mathrm{kg} / \mathrm{m}^{2}\right) 22.2 \pm 2.2$, body weight $(\mathrm{kg})$ $63.9 \pm 11.0$, body fat $\% 28 \pm 5$, fat free mass $(\mathrm{kg})$ $48.1 \pm 5.8)$. For the men the physical characteristics were: (mean $\pm \mathrm{SD}$ ): age (yr) $24 \pm 5$, BMI $\left(\mathrm{kg} / \mathrm{m}^{2}\right)$ $22.7 \pm 2.1$, body weight (kg) $76.2 \pm 9.4$, body fat $\%$ $18 \pm \overline{5}$, fat free mass $(\mathrm{kg}) 63.3 \pm 10.2$. All subjects were of normal weight $(20<\mathrm{BMI}<26)$. Body composition was determined by underwater weighing, with simultaneous assessment of the residual lung volume by a helium dilution technique, in the fasting state. The percentage of body fat was calculated using the equation of Siri (1961). Exclusion criteria were: medication, heavy sporting ( $>4$ times a week), smoking, insufficient health with respect to blood pressure, diabetes, other illnesses, being overweight or obese, and dietary restraint (Westerterp-Plantenga et al., 1999).

\subsection{Procedure}

The studies took place at the Department of Human Biology, at the University of Maastricht. The women stayed twice for $48 \mathrm{~h}(21.00-21.00 \mathrm{~h})$ in the respiration chamber; once at $27^{\circ} \mathrm{C}\left(81^{\circ} \mathrm{F}\right)$ and once at $22^{\circ} \mathrm{C}\left(72^{\circ} \mathrm{F}\right)$, in random order. Each time a woman stayed in the chamber she was in the same phase of her menstrual cycle, to avoid possible effects of menstrual cycle phases on energy expenditure.

The men stayed twice for $60 \mathrm{~h}(20.00-8.00 \mathrm{~h})$ in the respiration chamber; once at $22^{\circ} \mathrm{C}\left(72^{\circ} \mathrm{F}\right)$, and once at $16^{\circ} \mathrm{C}\left(61^{\circ} \mathrm{F}\right)$, in random order. Thus, a within-subject design was applied.

Before and after each stay in the chamber, the body weight of the subjects was determined. The interval between each stay in the chamber was about four weeks for each subject.

\subsubsection{Respiration chamber}

The respiration chamber is a $14 \mathrm{~m}^{3}$ room furnished with a bed, chair, television, radio, telephone, intercom, computer, washbowl and a deep freeze toilet. The chamber gives the impression of a normal living room. Contact between the subjects and investigator is possible via an intercom or telephone. Two chambers, next to each other, are used at the same time. Visual contact is possible through a window between the two chambers and through a window in the door. A third window provides an outside view. Three air locks provide passage for the exchange of food, collection of urine and for sampling of blood. During the experiment, the temperature as well as the relative humidity $(55 \% \mathrm{rh})$ was almost constant in the chamber, at $22^{\circ} \mathrm{C}$ or $16^{\circ} \mathrm{C}$, during day and night. The range of temperature was $15.9-16.1^{\circ} \mathrm{C}$, or $21.9-22.1^{\circ} \mathrm{C}$, or $26.9-27.1^{\circ} \mathrm{C}$, respectively and the variation in relative humidity was $53-55 \%$ rh (Schoffelen et al., 1997).

\subsubsection{Clothing}

To prevent hiding of possible effects by adjusted clothing, subjects had to wear the same outfit both times. In study I, the clothing consisted of underwear, bermuda shorts, two T-shirts (all 100\% cotton), and a pair of sport shoes, without socks. In study II, the clothing consisted of underwear, one T-shirt, one cotton shirt, one jogging-shirt ( $70 \%$ cotton, $30 \%$ polyester), one pair of jogging trousers $(50 \%$ cotton, $50 \%$ polyester) and a pair of sport shoes without socks during the day. The insulation for the entire clothing was 0.6 clo in study I and 1.2 clo in study II (ISO 9920, 1995). At night, all subjects wore one T-shirt and they slept under a cotton sheet and a light duvet $(100 \%$ polyester; $375 \mathrm{~g} / \mathrm{m}^{2}$ ). The clothing was tried out before; it was comfortable for the subjects at the two temperatures a subject had to stay. 


\subsubsection{Daily activities}

A standard daily-activities protocol was applied, which described every hour, and sometimes every 15min, what the subjects were supposed to do. It included household activities, standardized extensive aerobic exercise, refreshing, and sedentary activities such as reading and watching television. The meal- and snack times were standardized.

The aerobic exercise was standardized by the type of music with a fixed rhythm from a radio-cassette, while the subjects performed the same step test (step height $=12 \mathrm{~cm}, 1 \mathrm{step} / 2 \mathrm{sec}$; alternating $5 \mathrm{~min}$ stepping 5 min sitting), controlled by the experimenter. This type of step test is at the level of $20 \%$ of the $\mathrm{VO}_{2}$ max, as determined with a bicycle ergometer. The airflow in the chamber was kept at $3300 \mathrm{l} / \mathrm{min}$, and it was not necessary to change this during this extensive exercise in order to keep the ambient temperature at a constant level (Schoffelen et al., 1997). The physical activity of the subjects was monitored by means of a validated radar system, based on the Doppler principle, which is able to detect also small movements like fidgeting, and movements during sleep (Bouten et al., 1995; Schoffelen et al., 1997). The radar output during experiments is corrected for the offset points (which are caused by air movements).

\subsubsection{Body temperature}

During the stay in the respiration chamber, skin and core temperature of the subjects was registered and their energy metabolism was determined.

Skin temperatures were registered continuously from 8.00 AM to 12.00 PM by means of thermistor surface contact probes (YSI Series 400 probes; accuracy士 $0.01^{\circ} \mathrm{C}$ ) fixed to the skin with thin, air-permeable adhesive surgical tape. Proximal skin temperatures were measured at the forehead and the infra-claviculaire zone; distal skin temperatures were measured at the hand, thigh and foot. The core temperatures were measured rectally during the night with a rectal probe about $10 \mathrm{~cm}$ internally; during the day this was measured with a conventional electronic thermometer, $>3.5 \mathrm{~cm}$ internally.

\subsubsection{Energy expenditure}

Energy expenditure of the subjects was calculated from oxygen consumption and carbon dioxide production (Weir, 1949). The respiration chamber was ventilated with fresh air at a rate of $70-801 / \mathrm{min}$. The ventilation rate was measured by a dry gasmeter (G4 Schlumberger, The Netherlands). A paramagnetic $\mathrm{O}_{2}$ analyzer (OA 184A, Servomex) and an infrared $\mathrm{CO}_{2}$ analyzer (Uras 3G, Hartmann \& Braun) were used to analyze the samples of the in- and out-going air. Ingoing air was analyzed once every $15 \mathrm{~min}$ and out-going air every $5 \mathrm{~min}$ (Schoffelen et al., 1997).

\subsubsection{Energy intake}

Feeding in energy balance took place by estimating energy expenditure by means of the Harris-Benedict equation (Harris and Benedict, 1919), which gives basal metabolic rate (BMR), and multiplying BMR by an estimated physical activity level (PAL) of 1.65 (Westerterp et al., 1998). After measuring energy expenditure, this estimation was adjusted to the realistic SMR and PAL. Energy requirement was calculated for each subject individually. The macronutrient composition: carbohydrate/protein/fat was $49 / 15 / 36$ percentage of energy respectively, and energy density was $4.5 \mathrm{~kJ} / \mathrm{g}$. The energy content and macronutrient composition were calculated using the Dutch food composition table (Voorlichtingsbureau voor de Voeding, 1992).

\subsubsection{Comfort}

Comfort ratings of the subjects, representing general physical wellbeing were monitored nine times in the course of each experimental day using $100 \mathrm{~mm}$ anchored visual analog scales (VAS). The questions asked how comfortable, satisfied, irritated, fit, the subjects felt, how agreeable the ambient temperature was found, and whether the clothing was found to be adapted to the surrounding temperature (anchored: not at all; very).

\subsubsection{Approval of the protocol}

The Medical Ethics Committee of the University of Maastricht had approved the study protocol.

\subsection{Data analysis}

To check whether the subjects were in energy balance, the difference in $24 \mathrm{~h}$ EE and energy intake (EI) was compared to a theoretical difference of 0 .

To assess the effect of ambient temperature on a possible relationship between body temperature measurements and NST3, the following parameters were calculated following standard operating procedures (Ravussin et al., 1986; Bouten et al., 1995; Westerterp et al., 1998):

- $24 \mathrm{~h} \mathrm{EE}$

- SMR as the lowest mean energy expenditure from 7 values over $3 \mathrm{~h}$, in the post-absorptive phase, between 2.30 and $6 \mathrm{AM}$.

- $24 \mathrm{~h}$ DEE as the increase of energy expenditure above SMR, corrected for AEE. EE was plotted against radar output. The intercept of the regression line, at the offset of the radar is REE, consisting of SMR and DEE. DEE $=$ REE - SMR.

- NST3 as the difference between the relative DEE at the two ambient temperatures.

- $\mathrm{AEE}=\mathrm{EE}-\mathrm{REE}$

- body (skin) temperatures (i.e. core, proximal and distal temperatures) 
The possible relationship between body temperature measurements and NST3 was assessed by regression analysis for each group of subjects separately.

Statistical analyses, i.e. ANOVA repeated measures and regression analysis was carried out using the statistical software program STATVIEW SE+GRAPHICS; Abacus concepts, Inc, Berkeley, CA. Outcomes were regarded as statistically different if $p<0.05$.

\section{Results}

Energy balance appeared to be achieved, and body weight remained constant during the experiments. Subjects felt comfortable at each ambient temperature $(75 \pm 4 \mathrm{~mm}$ VAS). In study I, core $(p<0.05)$, proximal, and distal skin $(p<0.001)$ temperatures had decreased (Fig. 1a). EE had increased at $22^{\circ} \mathrm{C}: 9.9 \mathrm{MJ} / \mathrm{d}$ versus $8.9 \mathrm{MJ} / \mathrm{d}$ at $27^{\circ} \mathrm{C}(p<0.001)$ (Fig. 2) due to increases in DEE $(p<0.01)$, NST3 $(p<0.01)$ and AEE $(p<0.01)$. SMR had hardly changed.

In study II, core, proximal, and distal skin temperatures had decreased $(p<0.01)$ (Fig. 1b). EE had increased at $16^{\circ} \mathrm{C}: 12.9 \pm 2.0 \mathrm{MJ} / \mathrm{d}$ versus $12.2 \pm 2.2 \mathrm{MJ} / \mathrm{d}$ at $22^{\circ} \mathrm{C}$ $(p<0.001)$ (Fig. 2) due to increases in DEE $(p<0.01)$, NST3 $(p<0.01)$ and SMR $(p<0.05)$ (Westerterp-Plantenga et al., 2001a, b, submitted for publication).

The relative DEE in study I was $7.5 \pm 0.9 \%$ at $27^{\circ} \mathrm{C}$, and $10 \pm 2.1 \%$ at $22^{\circ} \mathrm{C} \quad(p<0.01)$. The difference, representing NST3 at $22^{\circ} \mathrm{C}$ was $248 \pm 208 \mathrm{~kJ} / \mathrm{d}$. The core-proximal gradient in body temperature was a function of NST3 $\left(y=-0.002 x+5.7 ; r^{2}=0.91\right.$; $p<0.001$ ) (Fig. 3).

The relative DEE in study II was $7.7 \pm 3.5 \%$ at $22^{\circ} \mathrm{C}$, and $13.3 \pm 2.7 \%$ at $16^{\circ} \mathrm{C}(p<0.01)$. The difference, representing NST3 at $16^{\circ} \mathrm{C}$ was $714 \pm 505 \mathrm{~kJ} / \mathrm{d}$. The core-proximal gradient in body temperature was a function of NST3 $\quad\left(y=-0.002 x+7.2 ; \quad r^{2}=0.46\right.$; $p<0.05$ ) (Fig. 3). Without the one outliner $y=$ $-0.001 x+7.0\left(r^{2}=0.66 ; p<0.01\right)$.
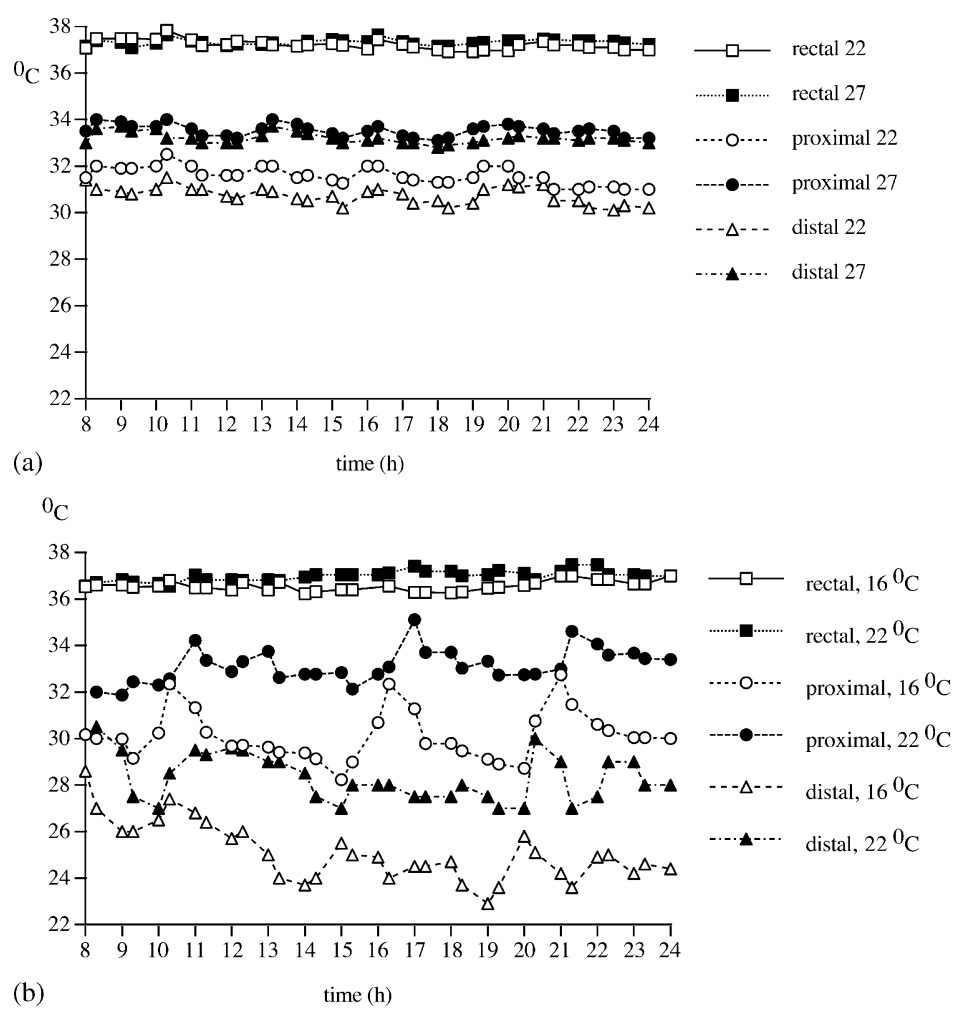

Fig. 1. (a) Example of body temperatures of a woman at an ambient temperature of $22^{\circ} \mathrm{C}$ (open symbols) and of $27^{\circ} \mathrm{C}$ (closed symbols), during $24 \mathrm{~h}$ out of $48 \mathrm{~h}$ in a respiration chamber. Physical activity: $10-10.30 \mathrm{~h}$ and $16-16.30 \mathrm{~h} ; \mathrm{Meals}$ : $8.30-9.00 \mathrm{~h}$; $13.00-$ $14.00 \mathrm{~h} ; 19.00-20.00 \mathrm{~h}$. (b) Example of body temperatures of a man at an ambient temperature of $16^{\circ} \mathrm{C}$ (open symbols) and of $22^{\circ} \mathrm{C}$ (closed symbols), during $24 \mathrm{~h}$ out of $60 \mathrm{~h}$ in a respiration chamber. Physical Activity: 10-10.30 h and 16-16.30 h; Meals: 8.30-9.00 h; $13.00-14.00 \mathrm{~h} ; 19.00-20.00 \mathrm{~h}$. 


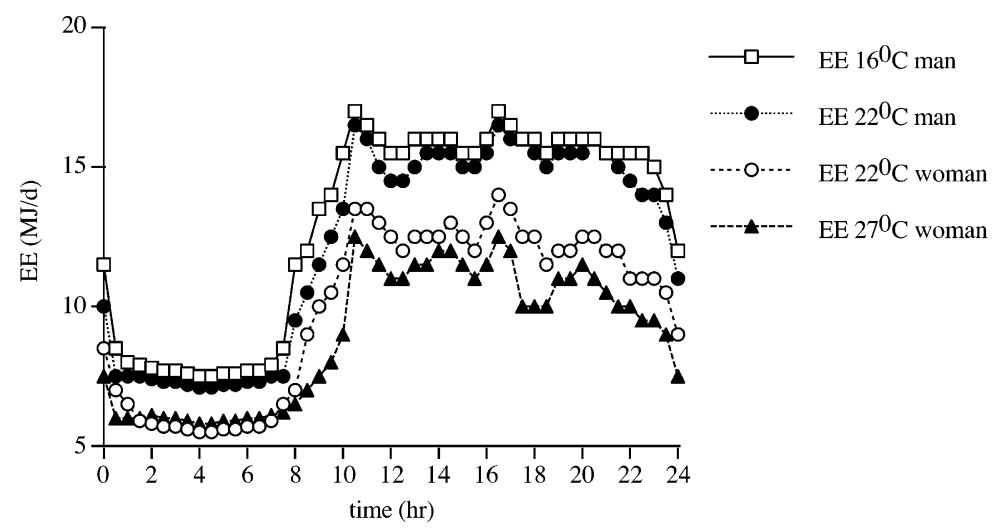

Fig. 2. Energy expenditure $(\mathrm{MJ} / \mathrm{d})$ of a representative man during energy balance at $16^{\circ} \mathrm{C}$ and $22^{\circ} \mathrm{C}$, and of a representative woman at $22^{\circ} \mathrm{C}$ and $27^{\circ} \mathrm{C}$, during $24 \mathrm{~h}$ in a respiration chamber. Sleeping metabolic rate: $3-6 \mathrm{~h}$; Physical activity: $10-10.30 \mathrm{~h}$ and $16-16.30 \mathrm{~h}$; Meals: $8.30-9.00 \mathrm{~h} ; 13.00-14.00 \mathrm{~h} ; 19.00-20.00 \mathrm{~h}$.

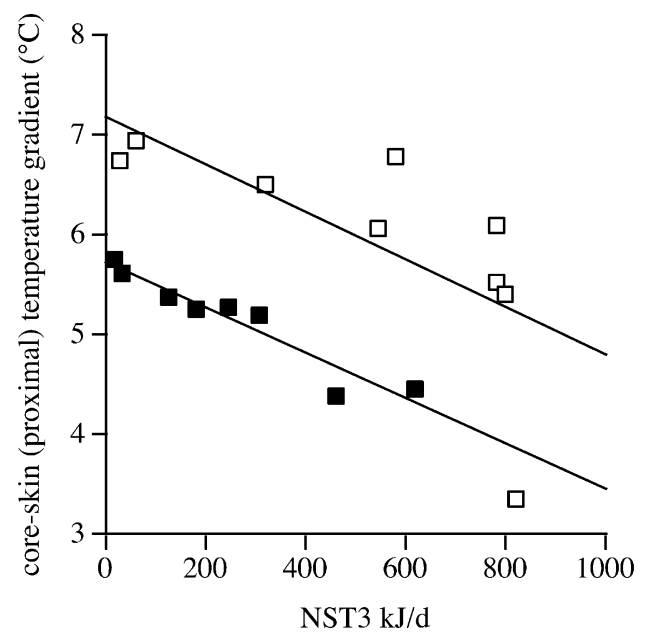

Fig. 3. The core-skin (proximal) temperature gradient in ${ }^{\circ} \mathrm{C}$ as a function of $\mathrm{NST} 3$ in $\mathrm{kJ} / \mathrm{d}$, at $22^{\circ} \mathrm{C}$ (filled symbols) $n=8$ women (age $23 \pm 2 \mathrm{yr}$, BMI $\left.\left(\mathrm{kg} / \mathrm{m}^{2}\right) 22.2 \pm 3.2\right)$ Regression equation: $y=-0.002 x+5.7 ; r^{2}=0.91 ; p<0.001$. The coreskin (proximal) temperature gradient in ${ }^{\circ} \mathrm{C}$ as a function of NST3 in $\mathrm{kJ} / \mathrm{d}$, at $16^{\circ} \mathrm{C}$ (open symbols) $n=9$ men (age $24 \pm 5 \mathrm{yr}$, BMI $\left.\left(\mathrm{kg} / \mathrm{m}^{2}\right) 22.7 \pm 2.1\right)$ Regression equation: $y=-0.002 x+$ $7.2 ; r^{2}=0.46 ; p<0.05$.

\section{Discussion}

In men, as well as in women, we showed an inverse relationship between the core-proximal (skin) temperature gradient and NST3. Excluding the outliner in Fig. 2, although there is no reason for that, the relationship is relatively stronger, but the slope becomes less steep. The results indicate that NST3 indeed contributes to body temperature regulation. The calculation of NST3 is a plausible approach because, based upon macronutrient compositions and meal sizes relative to energy balance, relative DEE should have been the same at the two ambient temperatures (Rothwell et al., 1990; Reed and Hill, 1996; Westerterp-Plantenga et al., 1990, 1992, 1999).

In earlier studies, it has been stated already that a facultative part of DEE contributes, like cold-induced thermogenesis, to heat production in the body (Rothwell et al., 1990), but a relationship between NST3 and a temperature regulation measurement, namely core-skin body temperature gradient, has not been shown before. That NST3 was present at $22^{\circ} \mathrm{C}$ (study I) as well as at $16^{\circ} \mathrm{C}$ (study II) which means that at the higher temperatures $\left(27^{\circ} \mathrm{C}\right.$ and $22^{\circ} \mathrm{C}$, respectively), there still must have been NST2 in the part of REE. However, DEE might have been overestimated by the difference between REE and SMR, and the increase in REE might also have been due to increases in muscle tone. In the men SMR was increased as well, which might have been due to increased muscle tone and an increase in NST1.

Only Nielsen (1987) reported data on core body temperature and skin temperature from a study in which a situation with a large breakfast was compared with a fasting situation, while subjects were resting. With the breakfast it appeared that parallel to an increase in energy expenditure, core body temperature increased and skin temperature increased to a larger extent, thus decreasing the core-skin body temperature gradient. Unfortunately, those data have not been analyzed to reveal this relationship; thus, we only can notice the coincidence from the reported figures.

Previously, we reported a relatively lower DEE after a meal in the obese and in dietary restrained subjects (who are vulnerable to obesity), together with a lack of increase in the skin temperature in the proximity of the liver (Westerterp-Plantenga et al., 1990, 1992). We now 
suggest that such a limited DEE and the reduced ability for thermogenesis in body temperature regulation in the obese in general (Contaldo et al., 1986) or in those who are vulnerable to obesity, may be related, and therefore may be a factor in the development of obesity.

However, more research is needed to show the (lack of) contribution of NST3 to the body temperature regulation in the development of obesity.

\section{References}

Blaza, S., Garrow, J.S., 1983. Thermogenic response to temperature, exercise and food stimuli in lean and obese women, studied by $24 \mathrm{~h}$ direct calorimetry. Br. J. Nutr. 49 , 171-180.

Bouten, C.V.C., Pannemans, D.L.E., Westerterp, K.R., Verduin, M., 1995. Physical activity assessment during standardized activity in a respiration chamber: movement registration versus energy expenditure. Int. J. Obes. Relat. Metab. Disord. 19, 29-36.

Contaldo, F., Scalfi, L., Coltorti, A., Lanzilli, A., 1986. Reduced cold-induced thermogenesis in familial human obesity. Klin. Wochenschr. 64, 177-180.

Dauncey, M.J., 1981. Influence of mild cold on $24 \mathrm{~h}$ energy expenditure, resting metabolism and diet-induced thermogenesis. Br. J. Nutr. 45, 257-267.

Hardy, J.D., Du Bois, E.F., 1934. Basal Metabolism, radiation, convection and vaporization at temperatures of $22-35^{\circ} \mathrm{C}$. J. Nutr. 8, 695.

Hardy, J.D., Du Bois, E.F., 1940. Differences between men and women in their response to heat and cold. Proc. Nat. Acad. Sci. 26, 389-398.

Harris, J.A., Benedict, F.G., 1919. A Biometric Study of Basal Metabolism in Man. Carnegie Institute, Washington DC, Publication 279, 1-266.

ISO 9920, 1995. Ergonomics of the Thermal EnvironmentEstimation of the Thermal Insulation and Evaporative Resistance of a Clothing Ensemble. IOS, Geneve, Switzerland.

Kraeuchi, K., Wirz-Justice, A., 1994. Circadian rhythm of heat production, heart rate, and skin and core temperature under unmasking conditions in men. Am. J. Physiol. 267, R819-R829.

Marken Lichtenbelt, W.D.v., Westerterp-Plantenga, M.S., Van Hoydonk, P., 2000. Individual variation in body temperature and energy expenditure in response to elevated ambient temperature. Environmental Ergonomics IX, Dortmund, Germany, Schaker Verlag, Aachen.

Nielsen, B., 1987. Does diet-induced thermogenesis change the preferred ambient temperature of humans? Eur. J. Appl. Physiol. 56, 474-478.
Ravussin, E.S., Lillioja, T.E., Anderson, L., Christin, C., Bogardus, C., 1986. Determinants of 24-energy expenditure in man. J. Clin. Invest. 78, 1568-1578.

Reed, G.W., Hill, J.O., 1996. Measuring the thermic effect of food. Am. J. Clin. Nutr. 63, 164-169.

Refinetti, R., 1997. Homeostasis and circadian rhythmicity in the control of body temperature. Ann. N. Y. Acad. Sci. 813, 63-70.

Rothwell, N.J., Stock, M.J., Stribling, D., 1990. Diet-induced thermogenesis. In: E. Schoenbaum, P. Lomax (Eds.), Thermoregulation, Physiology and Biochemistry, Chapter 13. In: W.C. Bowman (Ed.), International Encyclopedia of Pharmacology and Therapeutics, Section 131. Pergamon Press, Inc., Maxwell House, Fairview Park, Elmsford, New York 10523, USA, pp. 309-326.

Schoffelen, P.F.M.A., Westerterp, K.R., Saris, W.H.M., ten Hoor, F., 1997. A dual respiration chamber system with automated calibration. J. Appl. Physiol. 83, 2064-2072.

Siri, W.E., 1961. Body composition from fluid density: analysis of methods. In: Brozek, J., Herschel, A. (Eds.), Techniques for Measuring Body Composition. National Academy of Sciences, National Research Council, Washington, DC, pp. 233-244.

Voorlichtingsbureau voor de Voeding., 1992. De handleiding van de Voedingswijzer, Den Haag.

Weir, J.B.D.V., 1949. New methods for calculating metabolic rate with special reference to protein metabolism. J. Physiol. 109, 1-9.

Westerterp-Plantenga, M.S., Wouters, L., ten Hoor, F., 1990. Deceleration in cumulative food intake curves, changes in body temperature and diet-induced thermogenesis. Physiol. Behav. 48, 831-836.

Westerterp-Plantenga, M.S., van den Heuvel, E., Wouters, L., ten Hoor, F., 1992. Diet-induced thermogenesis and cumulative food intake curves as a function of familiarity with food and dietary restraint in humans. Physiol. Behav. 51, 457-465.

Westerterp-Plantenga, M.S., Rolland, V., Wilson, S.A.J., Westerterp, K.R., 1999. Satiety related to $24 \mathrm{~h}$ diet-induced thermogenesis during high protein/carbohydrate versus high fat diets measured in a respiration chamber. Eur. J. Clin. Nutr. 53, 495-502.

Westerterp-Plantenga, M.S., Top, S., Cilissen, C., van Marken Lichtenbelt, W.D., 2001a. Energy metabolism in women during a short exposure to an elevated ambient temperature. Submitted for publication.

Westerterp-Plantenga, M.S., van Marken Lichtenbelt, W. D., Strobbe, H., Schrauwen, P., 2001b. Energy metabolism and body weight in humans at a lowered ambient temperature. Submitted for publication.

Westerterp, K.R., Wilson, S.A.J., Rolland, V., 1998. Diet induced thermogenesis measured over $24 \mathrm{~h}$ in a respiration chamber: effect of diet composition. Int. J. Obes. Relat. Metab. Disord. 22, 1-6. 